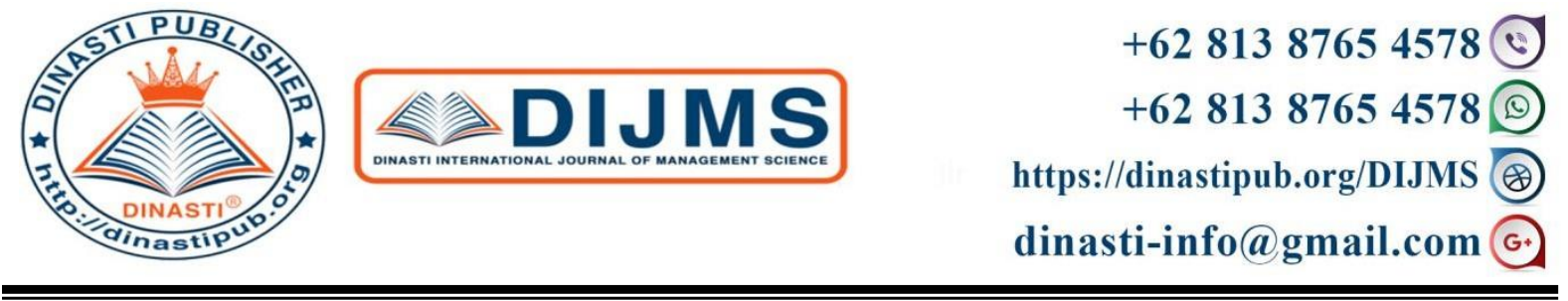

\title{
GREEN BRAND EFFECTS ON GREEN PURCHASE INTENTION (LIFE RESTAURANT NEVER ENDED)
}

\section{Rennyta Yusiana $^{1)}$, Arry Widodo ${ }^{2)}$, Agus Maolana Hidayat ${ }^{3)}$, Prima Kusuma Oktaviani ${ }^{4)}$} 1,2,3,4) Telkom University, Bandung, Indonesia

\begin{tabular}{|c|c|}
\hline $\begin{array}{l}\text { ARTICLE INFORMATION } \\
\text { Received: } 25^{\text {th }} \text { February } 2020 \\
\text { Revised: } 20^{\text {th }} \text { April } 2020 \\
\text { Issued: } 15^{\text {th }} \text { May } 2020 \\
\text { Corresponding author: } \\
\text { Rennyta Yusiana } \\
\text { E-mail: } \\
\text { rennyta@tass.telkomuniversity.ac.id }\end{array}$ & $\begin{array}{l}\text { Abstract: Currently the restaurant business is growing } \\
\text { rapidly in Bandung. This development occurred } \\
\text { because of the support of people's behavior to eat } \\
\text { outside the home. The issue of environmental damage } \\
\text { such as global warming and the greenhouse gas effect, } \\
\text { encouraging the emergence of restaurants that provide } \\
\text { healthy products and green products. This restaurant } \\
\text { appears in order to improve healthy behavior, reduce } \\
\text { waste, and provide education to people to live healthy } \\
\text { and to protect the environment. One of them is } \\
\text { Restoran Kehidupan Tidak Pernah Berakhir (KTPB) } \\
\text { which is a vegan restaurant in Indonesia that provides } \\
\text { a healthy lifestyle by eating only vegetables and to } \\
\text { educate consumers to consume green products. This } \\
\text { study aims to determine the effect of Green Brand } \\
\text { Positioning, Green Brand Knowledge, Attitude } \\
\text { Toward Green Brand in increasing Green Purchase } \\
\text { Intention. This research is a quantitative explanatory } \\
\text { study using } 400 \text { community respondents. Bandung. } \\
\text { The calculation and data processing will use Amos } \\
\text { software. The results showed that, Green Brand } \\
\text { Positioning has a significant impact on Green Brand } \\
\text { Knowledge and has significant implications for change } \\
\text { for Green Brand Attitude Towards and has a } \\
\text { significant influence on Green Purchase Intention. } \\
\text { Those variables have a significant impact on the Green } \\
\text { Purchase Intention for consumers Kehidupan Tidak } \\
\text { Pernah Berakhir Restaurants (KTPB). } \\
\text { Keywords: Green Brand Positioning, Green Brand } \\
\text { Knowledge, Attitude Toward Green Brand. }\end{array}$ \\
\hline
\end{tabular}




\section{INTRODUCTION}

Life's Restaurant Never Ends is a vegetarian restaurant in Bandung, which is an alternative choice for healthy living for all people who care about the environment, not to add to the effects of global warming with green products without animal processing.

Restaurant of Life Never End has a vision that Restaurant of Life Never End serves as self-serving (constructive) and wants to benefit the community and the world. As for the mission, Restaurant Life Never End has a mission to provide effective and targeted socialization to all levels of society (government officials, education, health, spirituality, mass media, artists, community leaders and the general public) about the benefits of a vegan lifestyle for environment, climate, health (body), mind and spirit (Company Documentation, 2019).

Education provided by Restaurant Life Never Ends gives more value to restaurants, because Restaurants Never End not only provides vegan food products but also provides education that will make visitors come more aware of the importance of maintaining health, the positive content present in vegetarian food and also the importance of protecting the environment because not all vegetarian restaurants do the same thing as Restaurant Life Never Ends. (Company Documentation, 2019). The many positive things provided by Restaurants Never End is not necessarily known by the entire community, and there are still many people who are less aware of the importance of consuming environmentally friendly products.

Therefore, this study proposes two concepts: green brand knowledge (GBK) and green brand attitude (AGB) to explore the relationship between green brand factors and GPI. This research will apply the knowledge-attitude-intention paradigm to build a comprehensive model for examining green brand factors that influence Green Purchase Intention (GPI).

\section{LITERATURE REVIEW}

\section{Green Marketing}

According to Yusiana.R \& Widodo.A (2016: 530), green marketing is a marketing mix planning process that utilizes changing consumer awareness of products / services that are more environmentally friendly by changing products, ways of making and packaging that are more environmentally friendly to satisfy and fulfill consumer needs and reduce negative impacts on the environment and also invites consumers to care more about the environment.

According to Dahlstrom (2011: 5) green marketing is a product offering that is not harmful to the environment and the production process is also not harmful to the environment. From these descriptions it can be concluded that Green Marketing is marketing environmentally friendly products and is able to reduce the negative impact of the environment by making environmentally friendly products from the product manufacturing process to its marketing. With this, it is expected to change the mindset of the community to better protect the environment.

According to (Haryani, 2010). Green marketing is divided into: 1. Green consumerism, (According to Boztepe; 2012) Green consumers are generally defined as people who adopt environmentally friendly behaviors or who buy green products. Green 
consumers are more internally controlled because they believe that it will be very effective in protecting the environment. 2. Green product or what can be known as an environmentally friendly or environmentally friendly product is a product that is designed and processed in a way to reduce the effects that can pollute the environment, both in production. Distribution and consumption. This can be attributed to the use of recycled products or raw materials.

\section{Green Product}

Green Products are goods that one of its characteristics is to use good materials, which can be recycled, and the process of making Green Products also uses good waste management, so that overall using green products means reducing carbon emissions, and helping to reduce the impact of global warming (Dahlstrom, 2011), divides green products in 3 dimensions:

1. Product that can be recycled

2. Durable product

3. Products that are guaranteed to be safe for the environment.

According to (Ottman, 2006) from the opinions of the experts above we can make a conclusion about the characteristics of green products, namely:

1. Product does not contain toxic

2. More durable product

3. The product uses raw materials that can be recycled

4. The product uses raw materials from recycled materials

5. The product does not use materials that can damage the environment

6. Does not involve product testing involving animals if it is not really necessary

7. During use does not damage the environment

8. Use simple packaging and provide refillable products

9. Does not endanger human and animal health

10. Does not consume a lot of energy and other resources during processing, use and sales

11. Does not produce waste that is not useful due to packaging in a short period of time

\section{Green Brand Knowledge}

According to Huang et al. (2014) Green Brand Knowledge is a green brand node in memory associated with various associations related to environmental commitment and environmental care. According to Keller (1993) in Suki (2016) "Green brand knowledge provides information about a product's unique brand attributes and its benefits to the overall environment to the consumers. The two types of brand knowledge are brand awareness and brand image. Green brand knowledge provides consumers with information about unique brand attributes and their benefits to the environment as a whole. Two types of brand knowledge are brand awareness and brand image. Thus it can be concluded that Green Brand Knowledge is knowledge about the brand, be it knowledge of attribute information, uniqueness, and other things that are expected to be useful for the environment. 


\section{Green Brand Positioning}

Green brand positioning is a critical brand strategy that influences the perception of target consumers towards green brand initiatives, providing the main basis for the differentiation of green brands from its competitors (Wang, 2017). According to Huang et al (2014: 257), green brand positioning is part of a brand identity and value proposition about the environmental attributes of a company that must be actively communicated to target customers. Huang et al divided green brand positioning into three dimensions, namely functional, emotional, and green.

\section{Attitude Towards Green Brand}

According to Teng (2009) in Huang et al. (2014), brand attitude is a reflection of consumer preferences that serve as an overall evaluation of a brand. Meanwhile, according to Salamon (2014) "Attitude towards a brand is allied to the consumers' preference and overall evaluation of a brand, which epitomizes their likes and dislikes. Attitudes towards brands are related to consumer preferences and overall brand evaluation, which symbolizes their likes and dislikes. From this statement it can be concluded that Attitude Towards Green Brand is the taste or preference of consumers towards a brand that is used as a thorough assessment to decide about purchasing a product, especially for products that are environmentally friendly and have a positive impact on the environment.

\section{Green Purchase Intention}

According to Huang et al (2014: 257) green purchase intention is the desire of consumers to buy a product after they realize it is a green product or a green brand. Green purchase intention is also measured using three items adapted from Chan in Huang et al (2014: 257) to study the intention of Chinese consumers involved in buying behavior of environmentally friendly products, namely: a. Consider buying products because they don't pollute the environment. b. Consider switching to another brand for ecological reasons. c. Planning to switch to an environmentally friendly product version. From this understanding the authors draw the conclusion that Green Purchase Intention is the intention of consumers to buy a product by considering the attributes possessed by the product so that it can protect the environment.

To further facilitate understanding of the research framework, this can be seen in Figure 1 as follows:

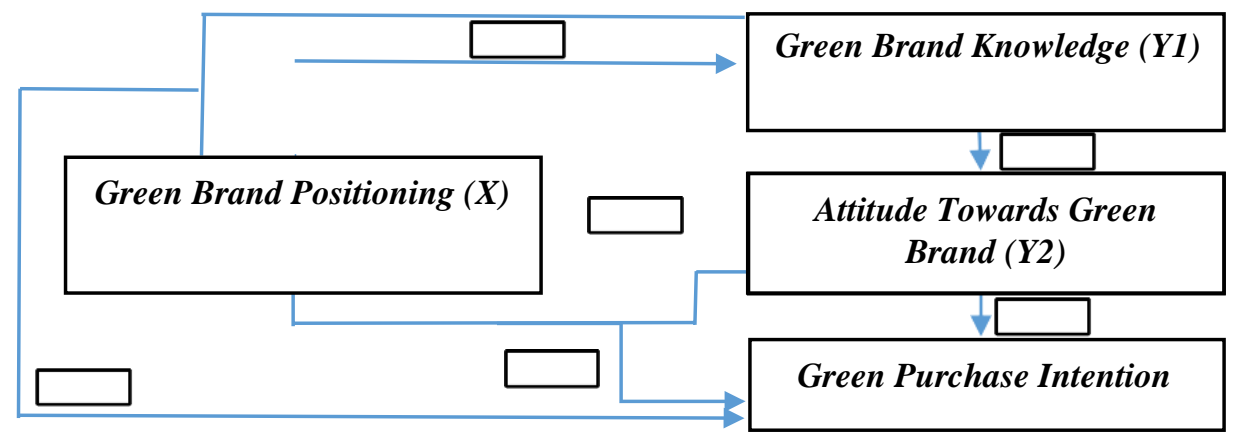

Figure 1. Framework for Thinking 


\section{RESEARCH METHODS}

In this study the authors used a quantitative research method that is a research method based on the philosophy of positivism, used to examine a particular population or sample, data collection using research instruments, quantitative / statistical data analysis, with the aim to test a predetermined hypothesis (Sugiyono, 2013).

\section{RESULTS AND DISCUSSION}

\section{Analysis Results}

Based on the calculation results show the relationship between variables, namely: Green Brand Knowledge (GBK), Green Brand Positioning (GBP), Green Brand Attitude Toward (ATGB) and Green Purchase Intention (GPI) are as follows:

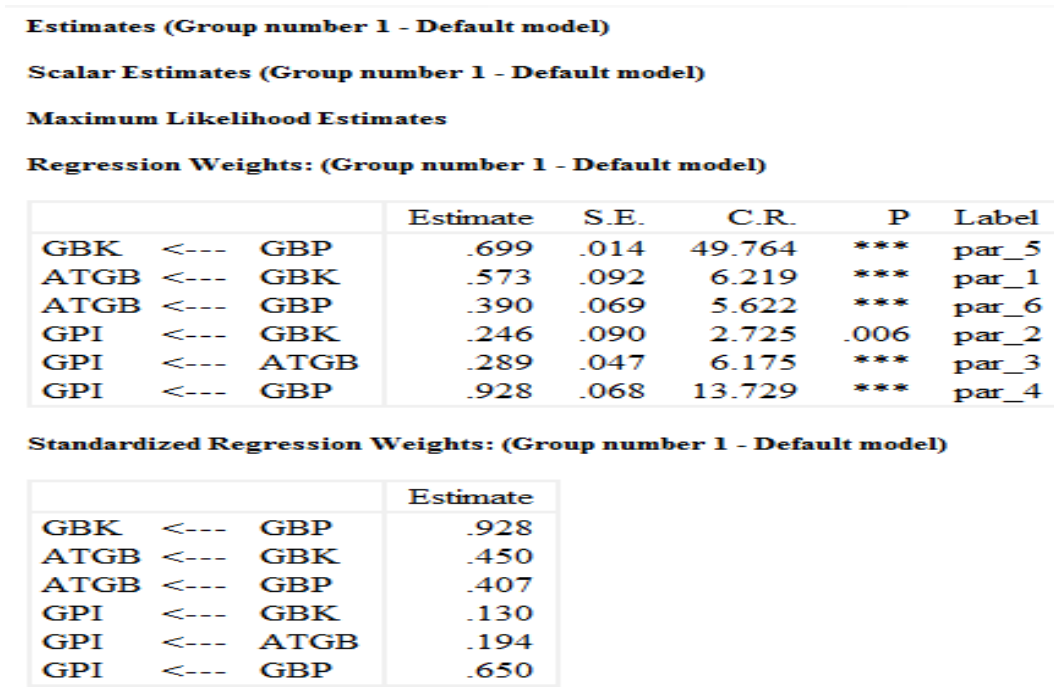

Based on the significance test on the estimated regression weight, it shows that the probability value is lower than 0.05 , which means that each variable shows a significant relationship between variables. However, based on the magnitude of the coefficient on standardized regression weights shows each has a different degree of closeness of the relationship between the variables.

The above equation model is a path analysis model, where the structural equation model can be explained in the figure below:

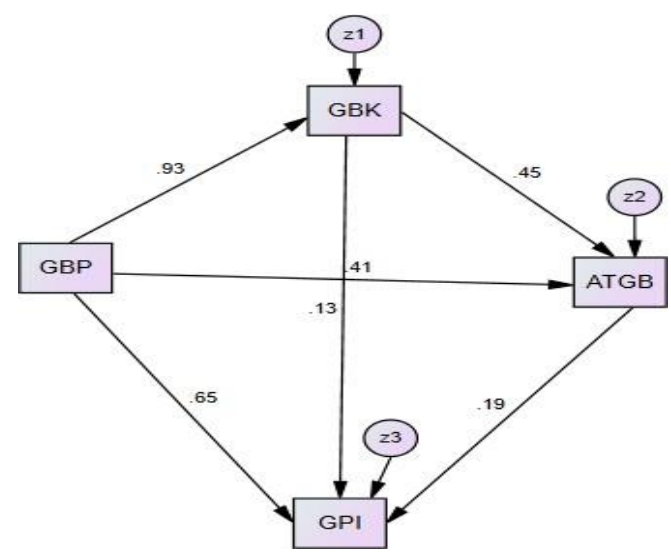

Figure 2. Path Analysis 
The picture shows that Green Brand Positioning (GBP) has a very strong direct relationship directly to Green Brand Knowledge (GBK) with a close coefficient value of 0.93. Furthermore, Green Brand Positioning (GBP) has a strong direct relationship to Attitude Toward Green Brand (ATGB) with a close coefficient value of 0.41. The Green Brand Positioning (GBP) has a strong direct relationship to Green Purchase Intention (GPI) with a closeness coefficient of 0.65. Then the Green Brand Knowledge (GBK) variable has a strong direct relationship to the Attitude Toward Green Brand (ATGB) with a close coefficient value of 0.45. Whereas each Green Brand Knowledge (GBK) and Attitude Toward Green Brand (ATGB) variables have a weak direct relationship to Green Purchase Intention (GPI), where the coefficient value is still below 0.20 , each 0.13 and 0.19 .

\section{CONCLUSION AND SUGESTION}

Based on the background stated, this study sets the following conclusions:

1. Green Brand Positioning (GBP) which includes Functional Positioning, Green Positioning and Emotional Positioning has a very strong positive direct relationship to Green Brand Knowledge (GBK).

2. Green Brand Positioning (GBP) which includes Functional Positioning, Green Positioning and Emotional Positioning has a strong enough positive direct relationship to Green Brand Attitude Towards (ATGB).

3. Green Brand Knowledge (GBK) which includes green brand awareness and green brand image has a strong positive direct relationship to Attitude Towards Green Brand (ATGB).

4. Attitude Towards Green Brand (ATGB) which includes Cognitive Element and Emotional Element has a positive relationship but is still weak towards Green Purchase Intention (GPI).

5. Together Green Brand Positioning (GBP) has a fairly strong relationship and Attitude Towards Green Brand (ATGB) has a positive relationship but is still weak towards Green Purchase Intention (GPI).

6. Simultaneously Green Brand Positioning (GBP) has a fairly strong positive relationship, but Green Brand Knowledge (GBK) and Attitude Towards Green Brand (ATGB) have a low positive relationship to green purchase intention (GPI).

\section{REFERENCE}

Akbar et al., 2014, 'Antecedents Affecting Customer's Purchase Intentions toward Green Products', Journal of Sociological Research, vol. 5, no. 1, ISSN 1948-5468.

Basuki, Agus Tri dan Nano Prawoto. 2016. Analisis Regresi dalam Penelitian Ekonomi dan Bisnis (Dilengkapi dengan SPSS dan Eviews). Yogyakarta: PT Rajagrafindo.

Dahlstrom, Robert. 2011. Green Marketing Management. United States of America: SouthWestern.

Echdar, Saban. 2017. Metode Penelitian Manajemen dan Bisnis: Panduan Komprehensif Langkah Demi Langkah Penelitian untuk Skripsi, Tesis, dan Disertasi: Ghalia Indonesia.

Huang, Yi-Chu, Minli Yang, Yu-Chun Wang. 2014. Effects of Green Brand on Green Purchase Intention. Marketing Intelligence \& Planning, Vol. 32 Issue: 3, pp.250-268 
Indrawati. 2015. Metode Penelitian Manajemen dan Bisnis Konvergensi Teknologi Komunikasi dan Informasi. Bandung: PT Refika Aditama.

Kotler, Philip dan Gary Armstrong. 2016. Principles of Marketing Sixteenth Edition: Global Edition. England: Pearson Education Limited.

Kotler, Philip dan Kevin Lane Keller. 2016. Marketing Management 15 Edition: Global Edition. England: Pearson Education Limited.

Kumar, P. dan B.M Ghodeswar. 2014. Factors Affecting Consumers' Green Product Purchase Decisions. Marketing Intelligence \& Planning. Vol. 33, No. 3, 330-347.

Kurniawati, Novia Ruli. 2017. Pengaruh Green Perceived Risk terhadap Green Purchase Intention yang Dimediasi oleh Green Trust (Studi pada Produk Lampu Philips LED di Kota Bandung). Skripsi. Universitas Telkom.

Kusumawati, Nila et al. 2017. Pengantar Statistika Penelitian. Depok: PT Rajagrafindo Persada.

Malhotra, N. K. 2015. Essentials of Marketing Research: A Hands-On Orientation. England: Pearson Education Limited.

Ottman, J. 2017. The New Rules of Green Marketing. San Francisco: Barrett-Koehler Publishers.

Pratama, Irvan Yuliandi. 2018. Pengaruh Consumer Guilt, Self Monitoring, Perceived Consumer Effectiveness terhadap Green Purchase Intemtion di Kota Bandung. Skripsi. Universitas Telkom.

Rukajat, Ajat. 2018. Pendekatan Penelitian Kuantitatif. Yogyakarta: Deepublish Publisher. Sudaryono. 2016. Manajemen Pemasaran: Teori dan Implementasi. Yogyakarta: CV. ANDI OFFSET.

Sugiyono. 2017. Metode Penelitian Manajemen. Cetakan Keenam. Bandung: Alfabeta.

Sugiyono. 2018. Metode Penelitian Manajemen. Cetakan Keenam. Bandung: Alfabeta.

Sujarweni, V. Wiratna. 2015. Metodologi Penelitian Bisnis \& Ekonomi, Cetakan Pertama. Yogyakarta: Pustaka Baru Press.

Suryanto, M. H. 2017. Metode Riset \& Analisis Saluran Distribusi: Model dan Pengukuran Kepuasan Pelanggan Saluran Distribusi. Jakarta: PT. Grasindo

Trijono, Rachmat. 2015. Metodologi Penelitian Kuantitatif. Jakarta: Papas Sinar Sinanti.

Tristiani, Rizky Izdihar. 2019. Pengaruh Green Brand Positioning, Attitude Toward Green Brand, dan Green Brand Knowledge terhadap Green Purchase Intention pada Motor GESITS di Kota Jakarta. Skripsi. Universitas Telkom.

Widodo. 2017. Metodologi Penelitian: Populer \& Praktis. Jakarta: PT. Rajagrafindo Persada. Wang, H.-J. 2017. A Brand-Based Perspective on Differentiation of Green Brand Positioning. Management Decision, 55(7), 1460-1475.

Yusiana, Rennyta dan Arry Widodo. 2015. Green Brand Dimension Affecting Consumer Intention Using Green Product. Bandung: American Scientific Publishers.

Yusiana, Rennyta, Arry Widodo, dan Cicilia Stevanie. 2015. Pengaruh Green Marketing terhadap Nilai yang Dipersepsikan dalam Keputusan Pembelian pada ADES (Studi Kasus pada Mahasiswa/I Fakultas Komunikasi dan Bisnis Telkom University). Indonesia: Journal Ecodemica. 